\title{
The Effect of Macro Information Environment Change on the Quality of Management Earnings Forecasts
}

\author{
Stephen P. Baginski* \\ University of Georgia \\ John M. Hassell \\ Indiana University \\ and \\ Michael D. Kimbrough \\ Harvard University
}

August 15, 2006

We thank Stephen Taylor, Ben Ayers, Linda Bamber, Rick Morton, Bruce Billings, Allen Bathke, Bok Baik, Isabel Wang, Eli Bartov, Paul Zarowin, Joshua Livnat, Carol Marquardt, Stephen Ryan, Eric Yeung and workshop participants at Florida State University, the University of New South Wales, the University of Melbourne, the University of Georgia and NYU for their helpful comments on earlier versions of this paper. We gratefully acknowledge the contribution of $\mathrm{I} / \mathrm{B} / \mathrm{E} / \mathrm{S}$ International Inc. for providing earnings per share forecast data. These data have been provided as part of a broad academic program to encourage earnings expectations research.

*Corresponding author:

Stephen P. Baginski

J.M. Tull School of Accounting

Terry College of Business

228 Brooks Hall

The University of Georgia

Athens, GA 30602-6252

Phone: 706-542-3608

Fax: 706-542-3630 


\title{
The Effect of Macro Information Environment Change on the Quality of Management Earnings Forecasts
}

\begin{abstract}
The 1990s were characterized by substantial increases in the performance of and investor reliance on financial analysts. Because managers possess superior private information and issue forecasts to align investors' expectations with their own, we predict that managers increased the quality of their earnings forecasts during the 1990s in order to keep pace with the improved forward-looking information provided by financial analysts, upon which investors increasingly relied.

Using a sample of 2,437 management earnings forecasts, we document an increase in management earnings forecast precision, management earnings forecast accuracy, and managers' tendency to explain earnings forecasts in 1993-1996 relative to 1983-1986. Given that these forecast characteristics are linked to greater informativeness and credibility, we also document that the information content of management earnings forecasts, as measured by the strength of share price responses to forecast news, increased in 1993 -1996 relative to 1983-1986. As expected, the increased information content of management forecasts primarily occurred for firms covered by financial analysts.
\end{abstract}

Keywords Management forecasts; Information environment; Earnings quality

JEL Descriptors $\quad$ M40, M41, M49 


\section{Introduction}

The decade of the 1990's witnessed substantial changes in the capital markets information environment, including a substantial increase in the percentage of shares held by institutional investors (Gompers and Metrick 2001), broader financial analyst following (Barber, Lehavy, McNichols, and Trueman 2001), greater focus on the firms' ability to generate earnings that "meet or beat" expectations (Brown and Caylor 2005), increases in the accuracy and precision of financial analysts forecasts (Brown and Caylor 2005), and the widely held popular belief that earnings had "lost relevance" for equity security valuation. With respect to this latter change in information environment, studies using data extending into the mid-1990s find an intertemporal decline in the value relevance of earnings (e.g., Lev and Zarowin 1999; Francis and Schipper 1999), an intertemporal increase in the value relevance of quarterly earnings announcements (e.g., Landsman and Maydew 2002), and an increase in the information content of analyst reports through time (Francis, Schipper, and Vincent 2002a).

To date, however, evidence on intertemporal change in the quality of unaudited voluntary earnings disclosures by management is lacking. Such evidence is important given that a growing body of literature seeks to understand broad cross-sectional averages of intertemporal changes in mandated disclosure relevance conditional on voluntary preemptive and supplemental disclosures provided by management (e.g., Francis, Schipper, and Vincent 2002b; Lundholm and Meyers 2002; Gelb and Zarowin 2002).

To provide evidence on changes in the quality of unaudited voluntary disclosures over time, we compare cross-sectional average management earnings forecast characteristics in one four-year period beginning in 1993 and ending in 1996 to management earnings forecast characteristics occurring in a comparison period 10 years earlier (1983-1986). According to Brown and Caylor (2005), 1993 marks the beginning of a period in which the capital markets increased penalties for failure to meet or beat financial analysts expectations, indicating investors' increased reliance on the forward-looking information 
provided by financial analysts. The end of our sample period, 1996, represents the last year in which legal liability rules were effectively similar in the 1990s. ${ }^{1}$ The $1993-1996$ period is also a common "recent period" in the most recent studies that examine increased relevance of earnings releases and financial analyst reports, and thus represents an appropriate comparison sample to the prior work which dominates current thinking. ${ }^{2}$

Given the dramatic change in the macro information environment in the 1990s, driven by greater institutional investor demand for forward-looking information and satisfied by more precise, accurate, and influential analysts reports, we expect that, in the 1990s, managers would have responded to the higher information quality hurdle if they wished to align investor expectations with their own. Accordingly, we expect that managers released management forecasts during the 1990s that possessed characteristics indicative of higher quality - increased precision, increased accuracy, and increased explanation.

Using a sample of 2,437 management earnings forecasts, we document an increase in management forecast precision, forecast accuracy, and the tendency to explain forecasts with external attributions in 1993-1996 relative to 1983-1986. Given that these forecast characteristics are linked to increased information content, we also document that the information content of management forecasts

\footnotetext{
${ }^{1}$ The Private Securities Litigation Reform Act was passed in December 1995. The effectiveness of the Act in changing expected and management forecast behavior is not clear, at least for 1996. As noted by Baginski, Hassell, and Kimbrough (2002), several analyses indicate that, at least initially, the protections of the Act could be avoided by shifting the jurisdiction of the suit, and the evidence on the effectiveness of the Act is mixed. We leave 1996 forecasts in our sample to match the number of years in 1983-1986. However, we replicated all tests in this paper (not tabulated) with 1996 observations discarded. Our conclusions are identical.

${ }^{2}$ For example, Lev and Zarowin (1999) document a decline in earnings relevance over a period ending in 1996. Francis and Schipper (1999) document a decline in earnings relevance over a period ending in 1994. Landsman and Maydew (2002) find an intertemporal increase in the value relevance of quarterly earnings announcements over a period ending in 1998. Francis et al. (2002a) document increases in the information content of analyst reports with a sample spanning 1986-1995. These studies form the basis for current thinking in the area.
} 
increased during the period, and that the increases occur only for firms covered by financial analysts, as expected. $^{3}$

In contrast to prior work that documents cross-sectional differences in management response to firm-specific disclosure incentives, our results indicate that cross-sectional average management earnings forecast characteristics (precision, accuracy, explanation, and resulting information content) are sensitive to structural changes in market-level information environment, consistent with the expectations adjustment hypothesis (Ajinkya and Gift 1984; King, Pownall, and Waymire 1990). Changes in macrolevel information environment are economy-wide antecedents to management forecasting behavior, and thus, our work complements work on other economy-wide antecedents to management forecasting behavior, such as legal environment (Skinner 1999; Baginski et al. 2002).

Our results also pertain to the information environment in which earnings releases are priced. The increases in management earnings forecast relevance over time that we document, the increases in the information content of financial analyst reports over a similar time period documented by Francis, Schipper, and Vincent (2002a), and the increases in the information content of earnings releases documented by Landsman and Maydew (2002) call into question why so many studies document a decrease in earnings relevance. In other words, if reports that preempt earnings releases (i.e., analyst and management reports) are increasingly valuable to the market, and the subsequent reports of earnings are increasingly valuable to the market, why do long-window association studies report that earnings relevance has declined?

The remainder of the paper is organized as follows. In section II, we present the basis for our conjecture that management earnings forecast quality changed during the 1990s. In section III, we

\footnotetext{
${ }^{3}$ Also, using a similar sample size to tests that reject the null of equal occurrence of external attributions, we fail to reject the null of equal occurrence of internal attributions across periods. Because Baginski, Hassell, and Kimbrough (2004) document pricing effects of external but not internal attributions, this result is also consistent with the idea that changes occur in the set of management forecast characteristics that are linked to higher quality forecasts.
} 
describe the management earnings forecast sample. In section IV, we present results and robustness checks, and Section V concludes the paper.

\section{Basis for expecting change in management forecast quality}

Managers have incentives to issue credible forecasts to align investor expectations with their own (Ajinkya and Gift 1984; King et al. 1990). These incentives are sufficiently strong such that, although management earnings forecasts are voluntary and unaudited, management earnings forecasts move security prices (Patell 1976; Waymire 1984) and are viewed by the security market as at least as relevant to equity security pricing as actual earnings releases (Pownall and Waymire 1989).

The decade of the 1990's witnessed substantial changes in the capital markets information environment. Gompers and Metrick (2001) report a substantial increase in the percentage of shares held by institutional investors between 1980 and 1996, with large institutional investors doubling their ownership percentages. Ajinkya et al. (2005) argue that institutional investors demand greater disclosure of forward-looking information. Not surprisingly, financial analysts, the primary provider of earnings forecasts, have responded. Brown and Caylor (2005) note that post-1992 market conditions reflect "increased media coverage given to analyst forecasts, more analyst following, more firms covered by analysts, and temporal increases in both the accuracy and precision of financial analysts forecasts." Francis et al. (2002a) also document an increase in the information content of analyst reports between 1986 and 1995.

Given more precise, accurate, and influential analysts reports in the 1990s, managers face a higher information quality hurdle if they wish to align investor expectations with their own. Accordingly, we expect managers to release 1990s management earnings forecasts that possess characteristics indicative of higher quality - increased precision, increased accuracy, and increased explanation. Each characteristic has been linked by prior research to enhanced information content (Kim 
and Verrecchia 1991; Baginski et al. 1993, 2004; Williams 1996), and accordingly, we examine whether price reactions to 1990s management earnings forecasts are enhanced (relative to 1980s forecasts) because of their higher quality. To the extent that analyst coverage proxies for the change in market information environment, we do not expect to find this effect for firms not covered by financial analysts.

Our conjecture is at a macro-level. We expect the set of publicly-released management earnings forecasts to be of a higher quality in the 1990s. This condition will exist if a given set of firms increases forecast quality over time or if the set of firms that issues management forecasts in the 1990s issues higher quality forecasts than the (possibly different) set of firms that issued management forecasts in the 1980s. We do not attempt to distinguish between these two alternatives because they are predicated on firm-specific changes in the incentives to issue management forecasts. We focus instead on macro-level changes in the information environment during a period of time in which macro-level legal environment does not change, and we conjecture that the average effect of the macro-level change in information environment will be to create an average increase in management earnings forecast quality for the firms that issue such forecasts.

Several potential counterbalancing conditions exist which increase the tension in testing our conjecture that management earnings forecast quality increased in the 1990s. First, Matsumoto (2002) and Richardson, Teoh, and Wysocki (2004) examine the behavior of financial analyst forecast revisions during a reporting period as a proxy for management guidance, observing patterns of forecast revisions that suggest that analysts are "walked down" to earnings expectations that can be met or beaten. In fact, Richardson et al. (2004) find strong support for their walk down claim post 1992. Cotter, Tuna, and Wysocki (2003) examine public management guidance (post 1993) and find evidence that managers are successful in walking down analyst earnings expectations prior to the release of actual earnings to an expectation equal to or less than actual quarterly earnings. In the context of this expectations management "game," one could argue that managers might have an incentive to create a downward bias 
in analysts' expectations to ensure a later positive good news actual earnings announcement, thus compromising management forecast quality. Second, the incentives that enhance the role of management forecasts in adjusting earnings expectations also create the potential for managers to use an alternative route to meet or beat analyst forecasts; e.g., opportunistic management of the actual earning number through aggressive (or even fraudulent) accrual practices. If such practices have led to a 1990s decline in the relevance of earnings, per se, then management earnings forecast relevance may have likewise declined. Collins, Maydew, and Weiss (1997), Lev and Zarowin (1999), and Francis and Schipper (1999) provide empirical evidence of declining earnings relevance. Finally, if financial analyst forecast quality has increased at a greater rate through time relative to management earnings forecast quality, then the precision of prior expectations might be greater than the precision of the management forecast signal in the 1990s, and the ability of the managers information to move expectations would decrease in the 1990s (Kim and Verrecchia 1991).

\section{Sample and variable measurement}

We combined two existing management earnings forecast samples of both interim and annual results from the Dow Jones News Retrieval Service (DJNRS) for 1983-1986 and 1993-1996. ${ }^{4}$ As noted by Hirst, Koonce, and Venkataraman (2006), 1980-1995 represents a period of legal environment stability. Our sample ends one year after this stable period ends (through the year following passage of the Private Securities Litigation Reform Act in December of 1995). The four years of data matches the 1983-1986 period length, which we chose as our benchmark period because we had access to the hand-

\footnotetext{
4 Our DJNRS search keywords are: "expects earnings," "expects net," "expects income," "expects losses," "expects profits," "expects results," and three similar lists with first words "forecasts", "predicts", and "sees". To be classified as a management forecast, the article had to describe an expectation about future earnings. If the language was past tense or present tense, the article was not coded as a forecast. The forecast also had to be attributed to a company official or to the firm. The number of forecasts discarded at each step of our sample selection process and the reason the forecast did not make the final sample can be found in Baginski et al. $(1993,2004)$.
} 
gathered and coded management forecast data. ${ }^{5}$ We discarded qualitative (i.e., "general impression")

forecasts, forecasts for which we were unable to obtain sufficient data on COMPUSTAT and CRSP,

forecasts made more than one period ahead, and forecasts made after period end. Our final sample

consists of 2,437 forecasts, 1,486 from the early period and 951 from the later period. ${ }^{6}$

\section{Results}

\section{Differences in ex ante management earnings forecasts characteristics: Precision and attribution}

Initially, we examine changes in two management earnings forecast characteristics that should lead to greater influence on investors' expectations. More precise earnings forecasts should lead to greater revisions in investors' expectations (Baginski et al. 1993; Kim and Verrecchia 1991). Also, earnings forecasts issued with external attributions are associated with a higher response coefficient on unexpected earnings conveyed in a management forecast (Baginski et al. 2004).

Tables 1 presents univariate tests of the difference in management earnings forecast precision and tendency to issue an external attribution in the 1990s relative to the 1980s. PRECISE equals two for the most precise point forecasts, one for range forecasts, and zero for open-interval minimum and maximum type forecasts. Consistent with our conjecture that managers increased forecast quality during the 1990s (e.g., increased forecast precision), a significant difference exists $(\mathrm{p}<0.0001)$ between the

\footnotetext{
${ }^{5}$ Machine readable data bases from which management earnings forecasts can be drawn do not exist before 1993. Construction of large samples of 1980 s forecasts is a labor-intensive process, especially when multiple qualitative dimensions of the forecasts such as attributions and other forecast language must be quantified. As a result, few studies using hand-gathered management earnings forecasts exist relative to the substantial number of studies which re-use machine-readable, existing samples coded on the COMPUSTAT and CRSP tapes. Our decision to use existing samples from 1983-1986 and 1993-1996 minimizes data collection costs. Further, it maximizes power if the change in information environment was gradual over the 1983-1996 period. We are unable to document what occurred in 1987-1992, however, which represents a potential limitation of our study.

6 The downturn in sample size appears temporary as it does not persist into 1997 and 1998 if we use the same sampling procedure. Smaller numbers of forecasts in the early 1990's might have stimulated the PSLRA legislation, the goal of which was to increase public disclosure. Anilowski, Feng, and Skinner (2004) also report a substantial increase in management forecasts from the First Call database in 1997 and 1998 relative to 1995 and 1996.
} 
distribution of forecast forms in the two periods. In 1993-1996, a smaller percentage of the less precise maximum and minimum type forecasts are issued, and a higher percentage of the more precise point and range forecasts are issued.

Each forecast is also coded to reflect whether managers attributed forecasted performance to an external factor (EXTERNAL) such as competition and certain economic factors. Examples of external factors include change in market for product, general loss or gain of customers, weather catastrophe, order backlogs, tax or other law changes, SEC actions, other regulatory actions, expropriation by foreign governments, lawsuits or legal actions, competition issues, and involuntary accounting changes. Again, consistent with our conjecture that managers increased forecast quality during the 1990s (e.g., increased the tendency to explain forecasts with external attributions), a significant difference exists $(\mathrm{p}<0.0001)$ between the tendency to issue external attributions in the two periods. The 1993-1996 period has a higher percentage of forecasts accompanied by external attributions (56.5\%) relative to 1983-1986 $(46.6 \%)$.

For descriptive purposes, we also provide the distribution of internal attributions for the two periods. It is interesting to note that the incidence of internal attributions is nearly identical in the two periods $(38.8 \%$ and $39.2 \%, p=0.8419)$. Because Baginski et al. (2004) document pricing effects of external but not internal attributions, this result is also consistent with the idea that changes occur in the set of 1990s management forecast characteristics that are linked to higher quality forecasts.

In Table 2, Panel A, we again examine whether earnings forecast precision increased in the 1990s, controlling for cross-sectional determinants of forecast precision documented by Baginski and Hassell (1997). We estimate the following model using logistic regression:

$$
\text { PRECISE }_{i}=\tau_{0}+\tau_{1} \text { DAYS }_{i}+\tau_{2} \text { RABSUE }_{i}+\tau_{3} \text { SIGNUE }_{i}+\tau_{4} \text { LANAL }_{i}+\tau_{5} \text { RSIZE }_{i}+\tau_{6} \text { SHIFT }_{i}+\varepsilon_{\mathrm{i}}
$$


$D A Y S_{i}$ is the number of calendar days that the management earnings forecast precedes periodend. Shorter forecast horizons should yield more precise forecasts. Accordingly, we expect the $\tau_{1}<0$. $R A B S U E_{i}$ is the ranked absolute value of unexpected earnings (UEMF) conveyed in the management forecast, computed as follows:

$$
U E M F_{\mathrm{i}}=\left[M F_{\mathrm{i}}-\left(A F_{\mathrm{i}} \text { or } R W_{\mathrm{i}}\right)\right] / \text { Price }_{\mathrm{i}}
$$

where $M F_{\mathrm{i}}=$ the management forecast of EPS for firm i; $A F_{\mathrm{i}}=$ the median analyst forecast of EPS for firm i obtained from $I / B / E / S$ for the month preceding the management forecast; $R W_{\mathrm{i}}=$ the random walk forecast (seasonal random walk forecast) of EPS for firm i for annual (interim) management forecasts; and Price $_{\mathrm{i}}=$ day -2 security price for firm i. Forecasted earnings are explicit for point management forecasts. For range forecasts, we used the midpoint of the range; for minimum and maximum type forecasts, we used the disclosed lower or upper bound. $R A B S U E_{i}$ is a proxy for the variability of expected earnings, which we expect to be inversely related to forecast precision $\left(\tau_{2}<0\right)$. SIGNUE $E_{i}$ equals one if $U E M F_{\mathrm{i}} \geq 0$, and zero otherwise. Prior research documents that bad news tends to be released in imprecise form (e.g., Skinner 1984). Accordingly, we expect $\tau_{3}>0$. LANAL is the log of the number of financial analysts following the firm prior to the month of the management forecast to proxy for firmspecific differences in the demand for more precise information, which should increase management earnings forecast precision $\left(\tau_{4}>0\right) . R S I Z E_{i}$ is a proxy for the predisclosure information environment, measured as equity market value at the beginning of the year. To control for the likely effects of inflation over a nearly 13-year period, we rank the size of the firm within each 4-year period and standardize the ranks by the number of observations within each 4-year period, yielding a variable between zero and one. Larger values of $R S I Z E_{i}$ indicate greater amounts of predisclosure information about a firm, and thus, less ability of a precise forecast to move security prices. Consistent with Baginski and Hassell (1997), we expect $\tau_{5}<0$. 
We test our conjecture of an increase in management earnings forecast precision by examining the coefficient on $\mathrm{SHIFT}_{i}$, which equals one in 1993-1996 and zero in 1983-1986. We expect that managers chose to release more precise earnings forecasts in 1993-1996 (i.e., $\tau_{6}>0$ ). Although our conjecture is based on the idea that a market-wide increase in analyst coverage is one of the driving forces behind the increase in management earnings forecast precision, we include the number of analysts following the firms as one of the control variables, thus rendering the regression a conservative test of our conjecture. We also estimate our model for firms followed by analysts and those that are not. (LANAL is omitted from the model when examining firms not followed by analysts.) If analyst following identifies the set of firms for which the information environment changed, then we would expect higher precision for firms followed by analysts but not for firms not followed.

The results from estimating equation (1) are presented in Table 2, Panel A. Full sample results are consistent with our conjecture. The coefficient on SHIFT is reliably positive $(\mathrm{p}=0.0118)$, indicating that 1993-1996 management earnings forecasts are more precise than 1983-1986 management earnings forecasts. As expected, this result holds for the subsample of analyst followed firms $(p=0.0002)$, but not for the subsample of firms not followed by analysts $(\mathrm{p}=0.4571)$. Results on the control variables are generally consistent with prior research, which was limited to analyst followed firms in the 1980s (Baginski and Hassell 1997). Interestingly, for firms not followed, the forecast horizon variable (DAYS) is the only significant explanatory variable for forecast precision $(\mathrm{p}=0.0001)$.

For analogous reasons, we also estimate the following model to control for documented determinants of the tendency to explain a management earnings forecast with an external attribution:

$$
\operatorname{EXTERNAL~}_{i}=\tau_{0}+\tau_{1} \operatorname{RSIZE}_{i}+\tau_{2} \text { RABSUE }_{i}+\tau_{3} \operatorname{SIGNUE}_{i}+\tau_{4} S H I F T_{i}+\varepsilon_{\mathrm{i}}
$$

In exploratory tests, Baginski et al. (2004) find that external attributions are related to firm size, the absolute value of unexpected earnings, and the sign of unexpected earnings, each of which are not 
disclosure choices by management. ${ }^{7}$ The results of estimating equation (2) are reported in Table 2, Panel B. Consistent with the exploratory nature of prior research, we do not predict signs on the control variables. Our primary conjecture is that more external attributions are made in the 1990 s, which is indicated by a positive coefficient on SHIFT.

For the full sample, results indicate that more attributions are provided by larger firms $(\mathrm{p}=$ 0.0212), firms with smaller ranked absolute unexpected earnings in the management forecast ( $\mathrm{p}=$ 0.1058), and bad news as evidenced by a negative unexpected earnings conveyed in the management forecast $(\mathrm{p}=0.0010)$. After controlling for these non-choice variables which have been shown to be associated with the tendency to explain with external attributions, the coefficient on SHIFT is reliably positive $(\mathrm{p}=0.0001)$. The results on the SHIFT variable exist in the analyst followed subsample $(\mathrm{p}=$ 0.0008), but also unexpectedly in the subsample of firms not followed by analysts $(p=0.0351)$. A t-test on the difference between the coefficients in the two subsamples (not tabulated) indicates that the coefficient on SHIFT in the analyst followed sample is greater than the coefficient on SHIFT for firms not followed. However, the $\mathrm{p}$-value does not indicate a great degree of reliability $(\mathrm{p}=.0835$ in a onetailed test). ${ }^{8}$

\section{Differences in ex post management earnings forecast characteristics: Accuracy}

One would also expect higher quality management earnings forecasts to be more accurate.

Accordingly, we examine whether management earnings forecast accuracy increased in the 1990s and

\footnotetext{
7 External attributions are also issued with maximum type forecasts. However, forecast form is a management choice variable for which we do not wish to control. Nonetheless, we included an indicator variable for maximum type forecasts in an untabulated estimation of equation (2). It is significantly positive, as expected, but the conclusion about increased external attribution in the 1990's was unaffected.

${ }^{8}$ As noted previously, when we discard 1996 forecasts, are results our unaffected. The lone exception is that discarding 1996 forecasts yields a much weaker significance level on the SHIFT coefficient in the results for the subsample not followed by financial analysts $(\mathrm{p}=0.092)$. As a result, the SHIFT coefficient in the analyst followed subsample is larger than the SHIFT coefficient in the not followed sample, as expected, with a much higher reliability $(\mathrm{p}=0.0025)$.
} 
whether the increase in forecast accuracy kept pace with benchmark accuracy (financial analysts forecasts and mechanical forecasts). We achieve control over firm, time, horizon, and expectation model effects on accuracy by 1) comparing management earnings forecast accuracy to a benchmark that is firm and time-period specific; 2) replicating all tests within forecast horizon (annual/interim); and 3) replicating all tests for followed and unfollowed firms. Therefore, use no other control variables in the analysis.

Table 3 presents accuracy data for each subperiod across various partitions on forecast horizon and analyst following. The first column of data lists the absolute management forecast error:

$$
\text { MFACC } \left._{\mathrm{i}}=\mid M F_{\mathrm{i}}-\text { Actual EPS }_{\mathrm{i}}\right) \mid / \text { Price }_{\mathrm{i}}
$$

The second column lists absolute benchmark forecast error:

$$
\text { BENCHACC }_{\mathrm{i}}=\mid\left(A F_{\mathrm{i}} \text { or } R W_{\mathrm{i}}\right)-\text { Actual EPS }_{\mathrm{i}} \mid / \text { Price }_{\mathrm{i}}
$$

which represents the absolute value of the error in the consensus financial analyst forecast (random walk forecast) if the company is followed (not followed) by $\mathrm{I} / \mathrm{B} / \mathrm{E} / \mathrm{S}$ analysts prior to the management forecast. The difference between the two columns is the relative management forecast error:

$$
\text { RELATIVEACC } C_{\mathrm{i}}=M F A C C_{\mathrm{i}}-\text { BENCHACC }_{\mathrm{i}}
$$

Consistent with prior research, the far right column of Table 3 shows statistically significant negative values for the relative absolute management forecast error within each subperiod. Negative values indicate that the absolute management forecast error was smaller than the absolute benchmark forecast error (i.e., the management forecast was more accurate than the benchmark). This result holds regardless of the data partition. The third column reports the relative absolute error. The management forecasting accuracy advantage is no different in the 1990 s relative to the 1980 s (i.e., the "difference" is insignificantly different from zero) in three of the four subsamples. ${ }^{9}$

\footnotetext{
9 An exception is found in the annual management forecasts with no analyst coverage. The accuracy advantage of managers is higher in 1993 - 1996 relative to 1983 - 1986.
} 
Although financial analyst accuracy improved for both interim and annual forecasts in the 19931996 period, management accuracy also improved so that managers remained more accurate than financial analysts. Interpreting the accuracy results in isolation is somewhat dangerous given that managers might also control the actual earnings number through earnings management. However, combined with our finding of increased management earnings forecast precision and tendency to issue external attributions in the 1990s, the results in Table 3 point to higher quality management earnings forecasts during that period.

\section{Differences in management earnings forecast consequence: Information content}

Our findings so far create the expectation that management earnings forecast information content increased in the 1990s as well. Accordingly, we compare the statistical association of security prices and unexpected earnings between the two non-overlapping four-year periods. We measured security price reaction to the management earnings forecast over a three-day event day interval centered on the DJNRS date (day 0). We estimate market model parameters over a 200-day period ending 31 trading days before the management forecast using an equally-weighted market return. The three-day price reaction is the cumulative abnormal return $(C A R)$, defined as actual return on each day minus the expected return given by applying the previously estimated market model parameters to the actual market return.

Ajinkya and Gift (1984), Waymire (1984), and many others document a positive association between the unexpected earnings conveyed in a management forecast and cumulative abnormal returns. In our statistical tests, we use ranked unexpected earnings (RankUE) because Cheng, Hopwood, and McKeown (1992) document the improvement in explanatory power from using the rank transformation on unexpected earnings. ${ }^{10}$

\footnotetext{
10 Using raw unexpected earnings truncated at $100 \%$ of security price yields similar results, but slightly lower explanatory power.
} 
Table 4 shows the distributions of $C A R$ and $U E M F$ in the two periods. Mean and median $C A R$ are slightly more negative in 1993-1996 ( $\mathrm{p}<0.001$ and $\mathrm{p}=0.0046$, respectively), although mean and median UEMF are slightly more positive in 1993-1996 (only the difference in median is significant at a conventional level, $\mathrm{p}=0.0022$ ).

To test for increased management earnings forecast information content over time, we estimate the following ordinary least squares model in the cross-section:

$$
\operatorname{CAR}_{i}=\tau_{0}+\tau_{1} \operatorname{RankUE}_{i}+\tau_{2} \operatorname{SHIFT}_{i}+\tau_{3} \operatorname{SHIFT}^{*} \operatorname{RankUE}_{i}+\varepsilon_{\mathrm{i}}
$$

where SHIFT equals one in 1993-1996 and zero in 1983-1986. The more recent sample period has a far higher percentage of interim forecasts relative to annual forecasts $(\mathrm{p}<0.0001$, results not tabulated). Also, consistent with arguments in Brown and Caylor (2005), the number of firms followed by financial analysts also increased dramatically between the two periods $(\mathrm{p}<0.0001$, results not tabulated). Accordingly, we estimate equation (6) separately both for interim and annual forecasts and for analyst followed and not followed firms.

Table 5 presents results of estimating equation (6). Our primary interest is in the coefficients on SHIFT and SHIFT*RankUE. They measure the extent to which the price reaction to management earnings forecasts in 1993-1996 differs from the price reaction to management earnings forecasts in the prior period (1983-1986). The first entries in Panel A of the table are the regression results for the full sample of 2,437 forecasts. The coefficient on RankUE is significantly positive, as expected $(\mathrm{p}=0.0001)$, indicating a positive ordinal relationship between unexpected earnings in the management forecast and cumulative abnormal returns in the forecast period. The intercept is significantly negative $(\mathrm{p}=0.0001)$. The intercept shift $($ SHIFT) is significantly negative $(\mathrm{p}=0.0001)$, indicating that the 1990 s price reactions are more negative, earnings held constant. The slope shift $\left(S H I F T^{*} R a n k U E\right)$ is significantly positive $(\mathrm{p}=0.0001)$, indicating that the price reaction per dollar of unexpected earnings is greater in the 1990s. 
We expect that any increase in the relevance of management earnings forecasts in the $1990 \mathrm{~s}$ should be limited to the set of firms followed by financial analysts. When we split the sample into the 1,381 management forecasts preceded by an $\mathrm{I} / \mathrm{B} / \mathrm{E} / \mathrm{S}$ financial analyst forecasts (Analyst followed) and the 1,056 management forecasts for which an $\mathrm{I} / \mathrm{B} / \mathrm{E} / \mathrm{S}$ financial analyst forecast was not available (Not followed), the results documented in Panel A for the full sample only hold in the sample of analyst followed firms, as predicted $(\mathrm{p}=0.0001$ on each shift variable). Also, results on the set of firms not followed by financial analysts speak to the question of change in management earnings forecast relevance over time for firms for which the information environment did not change. Note that, for firms not followed, we are unable to reject the null hypothesis of equal management earnings forecast relevance over time. The coefficients on the shift variables are insignificant $(p=0.8390$ and 0.5527$)$.

Panels B and C in Table 3 replicate Panel A for annual forecasts $(n=1,243)$ and interim forecasts $(n=1,194)$ considered separately. Note that the results are invariant to whether the forecast relates to an annual or interim period. ${ }^{11}$ Capital market reactions to management earnings forecasts are magnified for both annual and interim forecasts in the 1993-1996 period (i.e., coefficients on both SHIFT and SHIFT*RankUE are significant). Again, the results for the shift variables hold only in the annual and interim samples followed by financial analysts.

\section{Information content robustness checks}

We performed four sets of supplemental tests to ensure the robustness of our results on the information content tests. First, we retain imprecise forecasts in our sample because they are

11 Management earnings forecasts are highly dispersed in event time. Therefore, the potential dependency in regression residuals is minimized. An exception to this event time dispersion occurs because we treat two forecasts issued at the same time as two separate observations (unexpected earnings conveyed in the forecast and forecast form can be different for the two forecasts). The most prevalent case is a fourth quarter forecast and an annual forecast in the same article, which occurs approximately $10 \%$ of the time. Splitting the sample into annual forecasts and interim forecasts also serves as a robustness check with respect to this residual dependency. 
representative of the typical management forecast, and forecast form is associated with forecast news (e.g., Skinner 1994). A cost of this approach is the potential measurement error in unexpected earnings conveyed in the management forecast. Accordingly, we re-ran equation (6) two additional times in which we used alternative approaches to computing unexpected earnings conveyed in the management forecasts. First, in order to abstract from magnitudes of unexpected earnings, we replaced RankUE with a variable equal to one if $U E$ was greater than or equal to zero, and zero otherwise, and we interacted SHIFT with this new "sign-only" variable. The results (not tabulated) yield identical conclusions with respect to our conjecture. Adjusted $\mathrm{R}^{2} \mathrm{~s}$ decrease slightly, indicating that removal of measurement error is more than offset by the loss of information from discarding the magnitudes of unexpected earnings captured by the ordinal ranking of $U E$.

Second, we discarded ambiguous management earnings forecast news where, as defined in Baginski, Hassell, and Waymire (1994), ambiguous good news disclosures include range estimates where the midpoint exceeds expected earnings but the lower bound is below expected earnings, and minimum estimates less than or equal to expected earnings; and ambiguous bad news disclosures include range estimates where the midpoint is less than expected earnings but the upper bound exceeds expected earnings, and maximum estimates where the upper bound is greater than or equal to expected earnings. Again, our results (not tabulated) are robust to this alternative specification.

Third, several studies (e.g. Easton and Zmijewski 1989; Collins and Kothari 1989) document that firm-specific earnings response coefficients vary both intertemporally and in the cross-section as a function of economy-wide (i.e., interest rate) and firm-specific (i.e., risk and growth) variables. Therefore, we have the potential for a correlated omitted variables problem if we do not control for these other determinants of earnings response coefficients, and they are correlated with the shift between our two calendar-based sub-samples. 
We believe that our design substantially mitigates any concern about these capitalization factorrelated omitted variables that are associated with earnings response coefficients. Managers self-select into our sample in each of the two periods. Management forecasts are issued by the largest and least risky firms (Cox 1985; Waymire 1985) with the lowest proprietary information, often proxied by growth opportunities (Bamber and Cheon 1998) and industry membership (Baginski et al. 2004). Because (1) our earnings response coefficient estimation is sample-wide rather than firm-specific, (2) the larger, less risky, lower growth opportunity firms have self-selected into the sample, and (3) no evidence exists that the self-selection process on size, risk, and growth varies intertemporally, it is unlikely that correlated omitted variables are a problem. Also, if differences in period-specific, economy-wide capitalization rates are driving our results, we would see significant regime shift variables in the sample of firms not followed by financial analysts (which we do not).

Nevertheless, we re-estimated equation (6) with additional controls for cross-sectional differences in expected earnings capitalization rates. We changed the unexpected earnings deflator by deflating by prior expected earnings rather than by security price. Collins and Kothari (1989) argue that this alternative deflation should yield earnings response coefficients that are less sensitive to the aforementioned cross-sectional and intertemporal determinants. Replacing price with earnings as a deflator is the same as adjusting the management forecast by the price to earnings ratio, which is a function of interest rates, risk factors, size, and growth, and which essentially captures the effects of these variables on the extent to which earnings are capitalized into price. Our conclusions are unaffected by the results of this alternative specification (results not tabulated). ${ }^{12}$

\footnotetext{
12 Changing the deflator from price to earnings creates a new set of problems (e.g., negative earnings, outliers, distributional properties of unexpected earnings, etc.). We use various truncation schemes, windsorization, and ranking to make sure that our conclusions based on the alternative deflator are robust. We also took another approach to controlling for expected capitalization differences across firms in which we maintained the original price deflator for unexpected earnings and added an additional slope shift variable, the product of the leading earnings to price ratio and unexpected earnings conveyed in the management forecast (UEMF). The coefficient estimate on the variable was significantly negative, as expected, indicating that price response to the unexpected earnings is lower
} 
Fourth, Brown and Kim (1991) use stock price association tests to document that the most recent $\mathrm{I} / \mathrm{B} / \mathrm{E} / \mathrm{S}$ analyst forecasts are a better proxy for market expectations than the consensus forecast. We use the consensus (i.e., median) I/B/E/S Summary forecast in our main tests rather than the most recent forecasts. In effect, we are assuming that the measurement error in using the consensus forecast as a proxy for market expectations in 1983-1986 is equal to the measurement error in using the consensus forecast in 1993-1996.

A fair test of whether measurement error has changed over time is difficult to construct. January 1, 1993 marks the approximate date on which I/B/E/S began to update analysts' forecasts on a daily basis, rather than on weekly or monthly basis as had been done in the past (Cooper, Day, and Lewis 2001). Therefore, the timeliness of the most recent forecast is likely to differ between our two sample periods, and using the most recent forecasts might bias our tests in favor of the expected increase in management forecast information content post-1992. Using the consensus forecast rather than the most recent forecasts is likely to mitigate the effects of this change in $\mathrm{I} / \mathrm{B} / \mathrm{E} / \mathrm{S}$ updating policy on our tests.

Rather than attempt to identify most recent forecasts under a changing forecast updating regime, we conducted two indirect tests to address the potential effects of different forecast timing within the I/B/E/S Summary file consensus forecast. First, we repeated our main tests with an additional interaction variable between the slope shift variable on ranked unexpected earnings (SHIFT*RankUE) and the ratio of the analyst forecast standard deviation to the median consensus analyst forecast. Because this ratio is derived from the I/B/E/S Summary file, it is a noisy measure of the precision of analysts' forecasts, with the noise coming from the fact that some forecasts are potentially stale (Brown and Han 1992). The new interaction variable captures the joint effect of prior forecast precision and the existence of stale forecasts on the extent to which the change in sample period affects the price/earnings relation. The coefficient

when capitalization rates are lower (i.e., earnings to prices is a smaller number) or insignificant. However, our conclusions on the shift variables in equation (6) were unaffected (results not tabulated). 
estimate on the interaction is significantly positive (results not tabulated) indicating that the stronger post 1992 pricing effects of management earnings forecasts are greater when the analyst forecast standard deviation is higher prior to the forecast. Most important to our study, the t-statistic on the primary slope shift variable on ranked unexpected earnings (SHIFT*RankUE) remains unchanged.

In our second indirect test, we divide the full sample into quartiles based on the number of days between the management earnings forecast and period end, and we repeat our main tests on each of the four samples. The age of any analyst forecast included in the consensus is minimized for long horizon management forecasts, and the likelihood of out-of-date forecasts is also minimized. We document that the coefficient on our main research variable $\left(S H I F T^{*}\right.$ RankUE) is significant in each quartile (results not tabulated). Most importantly, the coefficients and t-statistics on the main research variable in quartiles one and four are very similar. Thus, it is unlikely that our results are significantly affected by the use of I/B/E/S Summary data. ${ }^{13}$

\section{Summary, limitations, and conclusions}

We compare cross-sectional average management earnings forecast characteristics in one fouryear period beginning in 1993 and ending in 1996 to management earnings forecast characteristics occurring in a comparison period 10 years earlier (1983-1986). Given the dramatic change in the macro information environment in the 1990s, driven by greater institutional investor demand for forwardlooking information and satisfied by more precise, accurate, and influential analysts reports, we expect

13 Finally, Bradshaw (2003) provides a graph of the relation between EPS determined under GAAP and EPS as reported by I/B/E/S. These two variables closely align in 1983-1986, and they clearly diverge in 1993-1996. If post-1992 I/B/E/S analysts are forecasting and providing actuals based on what they believe are more value relevant numbers than provided by GAAP, then one would expect less measurement error in the expectation model post-1992. However, management forecasts issued post-1992 included rare references to special items, and it is not clear what earnings construct they are forecasting and whether that construct has changed over time. To test whether management forecasts have changed like analyst forecasts have over time, future research can consider whether pro forma earnings released by managers more closely align with management forecasts in more recent periods. 
managers to respond to the higher information quality hurdle if they wish to align investor expectations with their own. Accordingly, we expect managers to release 1990s management earnings forecasts that possess characteristics indicative of higher quality - increased precision, increased accuracy, and increased explanation.

Using a sample of 2,437 management earnings forecasts, we document an increase in management forecast precision, forecast accuracy, and the tendency to explain forecasts with external attributions in 1993-1996 relative to 1983-1986. Given that these forecast characteristics are linked to increased information content, we also document that the information content of management forecasts increased during the period, and that the increases occur only for firms covered by financial analysts, as expected.

A potential limitation of our study, common to all intertemporal work, is the existence of unidentified variables which are correlated with the passage of time and that explain increases in the dependent variable (in our case, precision, accuracy, external attribution, and information content). An element of our design that mitigates the potential impact of this limitation is our finding that management earnings forecast quality variables increase during the 1990s only for subsamples for which plausible explanations suggest such an increase. For example, management forecast precision does not increase in the 1990s for firms not followed by financial analysts. Another potential limitation of our study is the need to create large hand-gathered samples or to use existing samples that do not cover all periods of time. In this study, we do not use data from 1987-1992, and therefore we are unable to infer management earnings forecast quality during that time period. Additionally, management earnings forecasting is sufficiently sporadic to impede construction of powerful interrupted time-series tests on changes in firmspecific management forecasting behavior. As a result, we have to rely on cross-sectional tests with nonmanagement choice firm-specific control variables in many of our tests. Finally, the coding of qualitative 
data raises the potential for noise. Fortunately, our tests are sufficiently powerful to reject the statistical null hypotheses associated with our conjectures.

In a sample ending in 1998, Landsman and Maydew (2002) document that earnings releases (a management disclosure) have increased in quality in recent times. In a sample spanning 1986-1995, Francis et al. (2002a) document that analysts reports (a disclosure by information intermediaries) have increased in quality in recent times. We document that management earnings forecast quality has also increased in 1993-1996 relative to 1983-1996 by documenting both increases in ex ante determinants of usefulness (precision, accuracy, and explanation) and ex post realization of the expected usefulness (increased information content). Our findings are unique in that management earnings forecasts are also management disclosures, but unlike earnings releases, are unaudited, voluntary disclosures.

Our findings also relate to the work in Francis et al. (2000b) who attribute the increased information content of earnings releases to accompanying supplemental information. We document a similar increase in the information content of management earnings forecasts, which we attribute to the greater degree of precision and explanation associated with such forecasts. We find that information production to yield both more precision and more explanation in management forecast has also increased over time, and the resulting information content of management earnings forecasts has increased.

Additional research is necessary to more fully understand why several studies document a decline in earnings relevance when earnings disclosures appear to possess increased information content regardless of source (management or analyst), verification (audited or unaudited), mandate (voluntary or required), and focus (historical or forward-looking). Also, the presence of higher quality management forecasts adds an additional dimension to the interaction and possible substitution between competing information sources. 
TABLE 1

Univariate Differences Between Periods in Management Earnings Forecast Precision and Attributions Issued with Management Earnings Forecasts

\begin{tabular}{|c|c|c|}
\hline Variable & $\begin{array}{c}1983-1986 \\
\text { Observations }(\%)\end{array}$ & $\begin{array}{c}1993-1996 \\
\text { Observations (\%) }\end{array}$ \\
\hline \multicolumn{3}{|l|}{ PRECISE } \\
\hline Maximum $(P R E C I S E=0)$ & $274 \quad(18.4)$ & $(14.3)$ \\
\hline Minimum $(P R E C I S E=0)$ & $563 \quad(37.9)$ & $(30.5)$ \\
\hline Range $(P R E C I S E=1)$ & $283 \quad(19.0)$ & $270 \quad(28.4)$ \\
\hline Point $(P R E C I S E=2)$ & $366 \quad(24.6)$ & $255 \quad(26.8)$ \\
\hline Total & $1,486(100.0)$ & $951(100.0)$ \\
\hline
\end{tabular}

EXTERNAL

External attribution provided $(E X T E R N A L=1)$

\begin{tabular}{rr}
$692(46.6)$ & $537(56.5)$ \\
$794(53.4)$ & $414(43.5)$ \\
\hline $1,486(100.0)$ & $951(100.0)$
\end{tabular}

Total

$$
\chi^{2}=22.73(\mathrm{p}<0.0001)
$$

INTERNAL

Internal attribution provided $(I N T E R N A L=1)$

\begin{tabular}{rr}
$542(38.8)$ & $409(39.2)$ \\
$853(61.2)$ & $633(60.8)$ \\
\hline $1,395(100.0)$ & $951(100.0)$
\end{tabular}

Total

$\chi^{2}=0.04(\mathrm{p}=0.8419)$ 
TABLE 2

Intertemporal Changes in the Management Earnings Forecast Imprecision and Tendency to Provide External Attributions

\begin{tabular}{|c|c|c|c|c|c|c|c|}
\hline \multicolumn{8}{|c|}{$\begin{array}{l}\text { Model: PRECISE } E_{i}=\tau_{0}+\tau_{1} D A Y S_{i}+\tau_{2} R A B S U E_{i}+\tau_{3} S I G N U E_{i}+\tau_{4} L A N A L_{i}+\tau_{5} R_{S I Z E_{i}}+ \\
\text { (Note: } L A N A L \text { is omitted from the model when examining firms not followed by analysts.) }\end{array}$} \\
\hline \multirow[t]{2}{*}{ PANEL A } & \multirow[b]{2}{*}{$\begin{array}{l}\text { Predicted } \\
\text { sign }\end{array}$} & \multicolumn{2}{|c|}{ Full sample $(\mathrm{n}=2,437)$} & \multicolumn{2}{|c|}{ Analyst followed $(\mathrm{n}=1,381)$} & \multicolumn{2}{|c|}{ Not followed $(\mathrm{n}=1,056)$} \\
\hline & & $\begin{array}{c}\text { Coefficient } \\
\text { estimate }\end{array}$ & $\mathrm{p}$-value & $\begin{array}{c}\text { Coefficient } \\
\text { estimate }\end{array}$ & p-value & $\begin{array}{c}\text { Coefficient } \\
\text { estimate }\end{array}$ & p-value \\
\hline$D A Y S$ & - & -0.002 & 0.0001 & -0.002 & 0.0001 & -0.002 & 0.0001 \\
\hline$R A B S U E$ & - & 0.001 & 0.9991 & -0.001 & 0.0052 & 0.002 & 0.9991 \\
\hline$S I G N U E$ & + & 0.208 & 0.0047 & 0.573 & 0.0001 & -0.085 & 0.7414 \\
\hline$L A N A L$ & + & 0.098 & 0.0106 & 0.302 & 0.0014 & $\mathrm{~N} / \mathrm{A}$ & $\mathrm{N} / \mathrm{A}$ \\
\hline RSIZE & - & -0.250 & 0.0580 & -1.564 & 0.0002 & -0.085 & 0.4444 \\
\hline SHIFT & + & 0.189 & 0.0118 & 0.458 & 0.0002 & 0.016 & 0.4571 \\
\hline Model $\chi^{2}$ & & 71.77 & 0.0001 & 72.35 & 0.0001 & 72.36 & 0.0001 \\
\hline \multicolumn{8}{|c|}{ Model: $\quad$ EXTERNAL $L_{i}=\tau_{0}+\tau_{1}$ RSIZE $_{i}+\tau_{2}$ RABSUE $_{i}+\tau_{3} \operatorname{SIGNUE}_{i}+\tau_{4} \operatorname{SHIFT}_{i}+\varepsilon_{\mathrm{i}}$} \\
\hline \multirow[t]{2}{*}{ PANEL B } & & \multicolumn{2}{|c|}{ Full sample $(\mathrm{n}=2,437)$} & \multicolumn{2}{|c|}{ Analyst followed $(\mathrm{n}=1,381)$} & \multicolumn{2}{|c|}{ Not followed $(\mathrm{n}=1,056)$} \\
\hline & $\begin{array}{l}\text { Predicted } \\
\quad \text { sign }\end{array}$ & $\begin{array}{c}\text { Coefficient } \\
\text { estimate }\end{array}$ & p-value & $\begin{array}{c}\text { Coefficient } \\
\text { estimate }\end{array}$ & p-value & $\begin{array}{l}\text { Coefficient } \\
\text { estimate }\end{array}$ & p-value \\
\hline$R S I Z E$ & none & 0.330 & 0.0212 & 0.533 & 0.0887 & 0.252 & 0.5825 \\
\hline$R A B S U E$ & none & -0.001 & 0.1058 & -0.000 & 0.4566 & -0.001 & 0.0318 \\
\hline SIGNUE & none & -0.274 & 0.0010 & -0.154 & 0.1609 & -0.452 & 0.0009 \\
\hline SHIFT & + & 0.402 & 0.0001 & 0.371 & 0.0008 & 0.281 & 0.0351 \\
\hline Model $\chi^{2}$ & & 41.15 & 0.0001 & 21.52 & 0.0002 & 15.80 & 0.0017 \\
\hline
\end{tabular}

p-values are one-tailed when a sign is predicted.

PRECISE equals two for the most precise point forecasts, one for range forecasts, and zero for open-interval minimum and maximum type forecasts.

EXTERNAL equals one if the explanation for forecasted performance relates to an external factor, and zero otherwise.

$D A Y S_{i}$ is the number of calendar days that the management earnings forecast precedes period-end. 
$R A B S U E_{i}$ is the ranked absolute value of unexpected earnings ( $\left.U E M F\right)$ conveyed in the management forecast, computed as $U E M F_{\mathrm{i}}=\left[M F_{\mathrm{i}}-\left(A F_{\mathrm{i}}\right.\right.$ or $\left.\left.R W_{\mathrm{i}}\right)\right] /$ Price $_{\mathrm{i}}$, where $M F_{\mathrm{i}}=$ the management forecast of EPS for firm i; $A F_{\mathrm{i}}=$ the median analyst forecast of EPS for firm i obtained from $I / B / E / S$ for the month preceding the management forecast; $R W_{\mathrm{i}}=$ the random walk forecast (seasonal random walk forecast) of EPS for firm $\mathrm{i}$ for annual (interim) management forecasts; and Price $_{\mathrm{i}}=$ day -2 security price for firm i. Forecasted earnings are explicit for point management forecasts. For range forecasts, we used the midpoint of the range; for minimum and maximum type forecasts, we used the disclosed lower or upper bound.

$S I G N U E_{i}$ equals one if $U E M F_{\mathrm{i}} \geq 0$, and zero otherwise.

$L A N A L$ is the $\log$ of the number of financial analysts following the firm (plus one) prior to the month of the management forecast.

$R S I Z E_{i}$ is the ranked (within each four-year period) equity market value at the beginning of the year, standardized by the number of observations within each 4-year period, yielding a variable between zero and one.

SHIFT $_{i}$ equals one in 1993-1996 and zero in 1983-1986. 
TABLE 3

Benchmark and Management Forecast Accuracy in Each Period

\begin{tabular}{|c|c|c|c|}
\hline Sample & $\begin{array}{l}\text { Absolute } \\
\text { management } \\
\text { forecast error }\end{array}$ & $\begin{array}{l}\text { Absolute } \\
\text { benchmark } \\
\text { forecast error }\end{array}$ & $\begin{array}{l}\text { Relative absolute } \\
\text { management } \\
\text { forecast error }\end{array}$ \\
\hline \multicolumn{4}{|c|}{ Interim forecasts, Followed by analysts } \\
\hline $1993-1996(n=400)$ & 0.012 & 0.016 & $-0.004 * * *$ \\
\hline $1983-1986(n=159)$ & 0.027 & 0.035 & $-0.008 * * *$ \\
\hline Difference $^{\mathrm{a}}$ & $-0.015 * * *$ & $-0.019 * *$ & 0.004 \\
\hline \multicolumn{4}{|c|}{$\begin{array}{l}\text { Interim forecasts, Not followed by } \\
\text { analysts }\end{array}$} \\
\hline $1993-1996(n=169)$ & 0.025 & 0.031 & $-0.006 * * *$ \\
\hline $1983-1986(n=466)$ & 0.016 & 0.028 & $-0.012 * * *$ \\
\hline Difference $^{a}$ & $0.009 * * *$ & $0.003 * * *$ & 0.006 \\
\hline \multicolumn{4}{|c|}{ Annual forecasts, Followed by analysts } \\
\hline $1993-1996(\mathrm{n}=291)$ & 0.040 & 0.045 & $-0.005 * * *$ \\
\hline $1983-1986(\mathrm{n}=531)$ & 0.063 & 0.078 & $-0.015 * * *$ \\
\hline Difference $^{\mathrm{a}}$ & $-0.023 * * *$ & $-0.033^{*}$ & 0.010 \\
\hline \multicolumn{4}{|c|}{ Annual forecasts, Not followed by analysts } \\
\hline $1993-1996(\mathrm{n}=91)$ & 0.048 & 0.114 & $-0.066 * * *$ \\
\hline $1983-1986(\mathrm{n}=330)$ & $0.059^{\mathrm{b}}$ & 0.076 & $-0.017 * * *$ \\
\hline Difference $^{\mathrm{a}}$ & $-0.011 * *$ & $0.039 * * *$ & $-0.049 * *$ \\
\hline
\end{tabular}

a $* * *(* *, *)$ significant at $\mathrm{p}=0.01(0.05,0.10)$ in two-tailed Wilcoxon rank-sum test (signed rank test on relative management forecast error within subperiod).

${ }^{b}$ Influenced by a large positive outlier. When removed, the value is less than 0.048 , and the "difference" is positive. The Wilcoxon rank-sum test indicates that management forecast accuracy declined from 1983-1986 to 1993-1996.

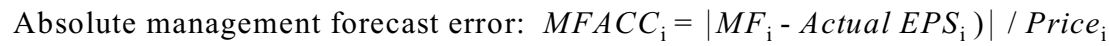

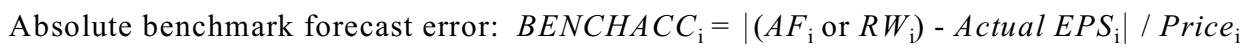

Relative management forecast error: $R E L A T I V E A C C_{\mathrm{i}}=M F A C C_{\mathrm{i}}-B E N C H A C C_{\mathrm{i}}$

$M F_{\mathrm{i}}=$ the management forecast of EPS for firm i; $A F_{\mathrm{i}}=$ the median analyst forecast of EPS for firm i obtained from $\mathrm{I} / \mathrm{B} / \mathrm{E} / \mathrm{S}$ for the month preceding the management forecast; $R W_{\mathrm{i}}=$ the random walk forecast (seasonal random walk forecast) of EPS for firm i for annual (interim) management forecasts; and Price $_{\mathrm{i}}=$ day -2 security price for firm $\mathrm{i}$. 
TABLE 4

Variable Distributions for Management Forecast Information Content Tests

\begin{tabular}{|c|c|c|c|c|c|c|}
\hline Variable & $\mathbf{N}$ & Mean & $\begin{array}{l}\text { Standard } \\
\text { Deviation }\end{array}$ & $\begin{array}{r}\text { Lower } \\
\text { Quartile }\end{array}$ & Median & $\begin{array}{c}\text { Upper } \\
\text { Quartile }\end{array}$ \\
\hline \multicolumn{7}{|l|}{$C A R$} \\
\hline 1983-1986 & 1,486 & -0.010 & 0.066 & -0.033 & -0.004 & 0.021 \\
\hline \multirow[t]{2}{*}{ 1993-1996 } & 951 & -0.028 & 0.114 & -0.069 & -0.009 & 0.029 \\
\hline & \multicolumn{4}{|c|}{$\begin{array}{c}\text { t-statistic on difference in means }=4.43(\mathrm{p}<0.001) \\
\text { Wilcoxon rank-sum test }=2.84(\mathrm{p}=0.0046)\end{array}$} & & \\
\hline \multicolumn{7}{|l|}{$U E M F$} \\
\hline 1983-1986 & 1,486 & 0.007 & 0.104 & -0.008 & 0.000 & 0.010 \\
\hline \multirow[t]{2}{*}{ 1993-1996 } & 951 & 0.012 & 0.086 & -0.005 & 0.001 & 0.012 \\
\hline & \multicolumn{6}{|c|}{$\begin{array}{l}\text { t-statistic on difference in means }=-1.37(\mathrm{p}=0.1710) \\
\text { Wilcoxon rank-sum test }=-3.06(\mathrm{p}=0.0022)\end{array}$} \\
\hline
\end{tabular}

$U E M F_{\mathrm{i}}=\left[M F_{\mathrm{i}}-\left(A F_{\mathrm{i}}\right.\right.$ or $\left.\left.R W_{\mathrm{i}}\right)\right] /$ Price $_{\mathrm{i}}$, where $M F_{\mathrm{i}}=$ the management forecast of EPS for firm $\mathrm{i} ; A F_{\mathrm{i}}=$ the median analyst forecast of EPS for firm i obtained from $\mathrm{I} / \mathrm{B} / \mathrm{E} / \mathrm{S}$ for the month preceding the management forecast; $R W_{\mathrm{i}}=$ the random walk forecast (seasonal random walk forecast) of EPS for firm i for annual (interim) management forecasts; and Price $_{\mathrm{i}}=$ day -2 security price for firm i. $C A R=$ the security price reaction to the management forecast over a three-day event day interval centered on the DJNRS date (day 0) using standard market model estimation techniques. 
TABLE 5

Intertemporal Changes in the Information Content of Management Earnings Forecasts

\begin{tabular}{|c|c|c|c|c|c|c|c|}
\hline \multirow[t]{2}{*}{ PANEL A } & \multirow[b]{2}{*}{$\begin{array}{l}\text { Predicted } \\
\text { sign }\end{array}$} & \multicolumn{2}{|c|}{ Full sample $(\mathrm{n}=2,437)$} & \multicolumn{2}{|c|}{ Analyst followed $(\mathrm{n}=1,381)$} & \multicolumn{2}{|c|}{ Not followed $(\mathrm{n}=1,056)$} \\
\hline & & $\begin{array}{l}\text { Coefficient } \\
\text { estimate }\end{array}$ & $\mathrm{p}$-value & $\begin{array}{c}\text { Coefficient } \\
\text { estimate }\end{array}$ & $\mathrm{p}$-value & $\begin{array}{l}\text { Coefficient } \\
\text { estimate }\end{array}$ & $\mathrm{p}$-value \\
\hline Intercept & none & -0.032 & 0.0001 & -0.024 & 0.0001 & -0.042 & 0.0001 \\
\hline RankUE & + & 0.019 & 0.0001 & 0.013 & 0.0014 & 0.026 & 0.0001 \\
\hline SHIFT & none & -0.053 & 0.0001 & -0.073 & 0.0001 & -0.003 & 0.8390 \\
\hline SHIFT*RankUE & + & 0.026 & 0.0001 & 0.038 & 0.0001 & -0.001 & 0.5527 \\
\hline Model F-statistic & & 60.93 & 0.0001 & 49.21 & 0.0001 & 14.55 & 0.0001 \\
\hline Adjusted $\mathrm{R}^{2}$ & & 0.0687 & & 0.0949 & & 0.0371 & \\
\hline $\begin{array}{l}\text { PANEL B } \\
\text { Annual } \\
\text { Forecasts }\end{array}$ & & \multicolumn{2}{|c|}{$\begin{array}{l}\text { Annual forecasts } \\
\qquad(\mathrm{n}=1,243)\end{array}$} & \multicolumn{2}{|c|}{$\begin{array}{l}\text { Annual forecasts with analyst } \\
\text { following }(\mathrm{n}=822)\end{array}$} & \multicolumn{2}{|c|}{$\begin{array}{l}\text { Annual forecasts without } \\
\text { analyst following }(\mathrm{n}= \\
\qquad 421)\end{array}$} \\
\hline Intercept & none & -0.020 & 0.0001 & -0.017 & 0.0014 & -0.027 & 0.0092 \\
\hline RankUE & + & 0.009 & 0.0025 & 0.009 & 0.0091 & 0.011 & 0.0422 \\
\hline SHIFT & none & -0.039 & 0.0001 & -0.046 & 0.0001 & -0.013 & 0.6188 \\
\hline SHIFT*RankUE & + & 0.021 & 0.0004 & 0.022 & 0.0005 & 0.013 & 0.1847 \\
\hline Model F-statistic & & 15.61 & 0.0001 & 16.31 & 0.0001 & 2.72 & 0.0440 \\
\hline Adjusted R ${ }^{2}$ & & 0.0341 & & 0.0503 & & 0.0122 & \\
\hline $\begin{array}{l}\text { PANEL C } \\
\text { Interim } \\
\text { Forecasts }\end{array}$ & & \multicolumn{2}{|c|}{$\begin{array}{l}\text { Interim forecasts } \\
\qquad(\mathrm{n}=1,194)\end{array}$} & \multicolumn{2}{|c|}{$\begin{array}{l}\text { Interim forecasts with analyst } \\
\text { following }(\mathrm{n}=559)\end{array}$} & \multicolumn{2}{|c|}{$\begin{array}{l}\text { Interim forecasts, without } \\
\text { analyst following }(\mathrm{n}= \\
635)\end{array}$} \\
\hline Intercept & none & -0.058 & 0.0001 & -0.056 & 0.0006 & -0.058 & 0.0001 \\
\hline RankUE & + & 0.040 & 0.0001 & 0.032 & 0.0074 & 0.042 & 0.0001 \\
\hline SHIFT & none & -0.047 & 0.0001 & -0.075 & 0.0002 & 0.041 & 0.3836 \\
\hline SHIFT*RankUE & + & 0.018 & 0.0196 & 0.043 & 0.0032 & -0.019 & 0.9604 \\
\hline Model F-statistic & & 48.75 & 0.0001 & 27.50 & 0.0001 & 17.81 & 0.0001 \\
\hline Adjusted $\mathrm{R}^{2}$ & & 0.1072 & & 0.1247 & & 0.0737 & \\
\hline
\end{tabular}

p-values are one-tailed when a sign is predicted.

Model CAR ${ }_{i}=\tau_{0}+\tau_{1} \operatorname{RankUE}_{i}+\tau_{2} \operatorname{SHIFT}_{i}+\tau_{3} \operatorname{SHIFT}^{*} \operatorname{RankUE}_{i}+\varepsilon_{\mathrm{i}}$

$\operatorname{RankUE}_{\mathrm{i}}=\operatorname{Rank}\left[M F_{\mathrm{i}}-\left(A F_{\mathrm{i}}\right.\right.$ or $\left.\left.R W_{\mathrm{i}}\right)\right] /$ Price $_{\mathrm{i}}$, where $M F_{\mathrm{i}}=$ the management forecast of EPS for firm $\mathrm{i} ; A F_{\mathrm{i}}=$ the median analyst forecast of EPS for firm i obtained from I/B/E/S for the month preceding the management forecast; $R W_{\mathrm{i}}=$ the random walk forecast (seasonal random walk forecast) of EPS for firm i for annual (interim) management forecasts; and Price $_{\mathrm{i}}=$ day -2 security price for firm i. $C A R=$ the security price reaction to the management forecast over a three-day event day interval centered on the DJNRS date (day 0) using standard market model estimation techniques. SHIFT=1 (0) for the 1993-1996 (19831986) period. Coefficients on ranked variables are multiplied by $10,000$. 


\section{References}

Ajinkya, B., S. Bhojraj, and P. Sengupta. 2005. The association between outside directors, institutional investors, and the properties of management earnings forecasts. Journal of Accounting Research 43: 343-376.

Ajinkya, B., and M. Gift. 1984. Corporate managers' earnings forecasts and symmetrical adjustments of market expectations. Journal of Accounting Research 22: 425-44.

Anilowski, C., M. Feng, and D. Skinner. 2004. Is guidance a macro factor? The nature and information content of aggregate earnings guidance. Working paper, University of Michigan.

Baginski, S., E. Conrad, and J. Hassell. 1993. The effects of management forecast precision on equity pricing and on the assessment of earnings uncertainty. The Accounting Review 68: 913-27.

Baginski, S., and J. Hassell. 1997. Determinants of management forecast precision. The Accounting Review 72: 303-312.

Baginski, S., J. Hassell, and M. Kimbrough. 2002. The effect of legal environment on voluntary disclosure: Evidence from management earnings forecasts issued in U.S. and Canadian markets. The Accounting Review 77: 25-50.

Baginski, S., J. Hassell, and M. Kimbrough. 2004. Why do managers explain their earnings forecasts?" Journal of Accounting Research 42: 1-29.

Baginski, S., J. Hassell, and G. Waymire. 1994. Some evidence on the news content of preliminary earnings estimates. The Accounting Review 69: 265-73.

Bamber, L. S., and Y. Cheon. 1998. Discretionary management earnings forecast disclosures: Antecedents and outcomes associated with venue and forecast specificity choices. Journal of Accounting Research 36: 167-190.

Barber, B., R. Lehavy, M. McNichols, and B. Trueman. 2001. Can investors profit from the prophets? Security analysts recommendations and stock returns. Journal of Finance 56: 531-563.

Bradshaw, M. 2003. A discussion of assessing the relative informativeness and permanence of pro forma earnings and GAAP operating earnings. Journal of Accounting and Economics 36: 321-35.

Brown, L., and M. Caylor. 2005. A temporal analysis of quarterly earnings thresholds: Propensities and valuation consequences. The Accounting Review 80: 423-440.

Brown, L., and J. Han. 1992. The impact of annual earnings announcements on the convergence of beliefs. The Accounting Review 67: 862-75.

Brown, L., and K-J. Kim. 1991. Timely aggregate analysts' forecasts as better proxies for market earnings expectations. Journal of Accounting Research 29: 382-85. 
Cheng, A., W. Hopwood, and J. McKeown. 1992. Non-linearity and specification problems in unexpected earnings response regression model. The Accounting Review 67: 579-598.

Collins, D., and S. P. Kothari. 1989. An analysis of intertemporal and cross-sectional determinants of earnings response coefficients. Journal of Accounting and Economics: 143-182.

Collins, D., E. Maydew, and I. Weiss. 1997. Changes in value-relevance of earnings and book values over the past forty years. Journal of Accounting and Economics 24: 39-68.

Cooper, R., T. Day, and C. Lewis. 2001. Following the leader: A study of individual analysts' earnings forecasts. Journal of Financial Economics 61: 383-416.

Cotter, J., I. Tuna, and P. Wysocki. 2003. Expectations management and beatable targets: How do analysts react to explicit earnings guidance? Working paper, MIT Sloan School of Management.

Cox, C. 1985. Further evidence on the representativeness of management earnings forecasts. The Accounting Review 60: 692-701.

Easton, P., and M. Zmijewski. 1989. Cross-sectional variation in the stock market response to accounting earnings announcements. Journal of Accounting and Economics 11:117-142.

Francis, J., and K. Schipper. 1999. Have financial statements lost their relevance? Journal of Accounting Research 37: 319-352.

Francis, J., K. Schipper, and L. Vincent. 2002a. Earnings announcements and competing information. Journal of Accounting and Economics 33: 313-342.

Francis, J., K. Schipper, and L. Vincent. 2002b. Earnings disclosures and the increased usefulness of earnings announcements. The Accounting Review 77: 515-546.

Gelb, D., and P. Zarowin. 2002. Corporate disclosure policy and the informativeness of stock prices. Review of Accounting Studies: 33-52.

Gompers, P., and A. Metrick. 2001. Institutional investors and equity prices. Quarterly Journal of Economics: 229-259.

Hirst, E., L. Koonce, and S. Venkataraman. 2006. Management earnings forecasts: A review and framework. Working paper, University of Texas at Austin.

Kim, O., and R. Verrecchia. 1991. Trading volume and price reactions to public announcements. Journal of Accounting Research 29: 302-321.

King, R., G. Pownall, and G. Waymire. 1990. Expectations adjustment via timely earnings forecast disclosure: Review, synthesis, and suggestions for future research. Journal of Accounting Literature 9: 113-44.

Landsman, W, and E. Maydew. 2002. Has the information content of quarterly earnings announcements declined in the past three decades? Journal of Accounting Research 40: 797-808. 
Lev, B., and P. Zarowin. 1999. The boundaries of financial reporting and how to extend them. Journal of Accounting Research 37: 353-386.

Lundholm, R., and L. Myers. 2002. Bringing the future forward: The effect of disclosure on the returnsearnings relation. Journal of Accounting Research 40: 809-840.

Matsumoto, D. 2002. Management's incentives to avoid negative earnings surprises. The Accounting Review 77: 483-514.

Patell, J. 1976. Corporate forecasts of earnings per share and stock price behavior: Empirical tests. Journal of Accounting Research: 246-76.

Pownall, G. and G. Waymire. 1989. Voluntary disclosure credibility and securities prices: Evidence from management earnings forecasts, 1969-73. Journal of Accounting Research 27: 227-245.

Richardson, S., S. Teoh, and P. Wysocki. 2004. The walkdown to beatable analyst forecasts: The roles of equity issuance and insider trading incentives. Contemporary Accounting Research 21: 885-924.

Skinner, D. 1994. Why firms voluntarily disclose bad news. Journal of Accounting Research:3860 .

Waymire, G. 1984. Additional evidence on the information content of management earnings forecasts. Journal of Accounting Research 22: 703-718.

Waymire, G. 1985. Earnings volatility and voluntary management forecast disclosure. Journal of Accounting Research 23: 268-295.

Williams, P. 1996. The relation between prior earnings forecasts by management and analyst response to a current management forecast. The Accounting Review 71: 103-113. 